\title{
Pengaruh Persiapan Lahan dan Penataan Lahan terhadap Sifat Tanah, Pertumbuhan dan Hasil Cabai Merah (Capsicum annum) di Lahan Gambut
}

\section{Effect of Land Preparation and Land Arragement on Soil Properties, Growth and Yield of Red Pepper (Capsicum annum) in Peat land}

\author{
Eni Maftuah $^{1 *}$ dan Afiah Hayati ${ }^{2}$ \\ Diterima 04 Feruari 2019/Disetujui 18 Juni 2019
}

\begin{abstract}
Peatlands are potential to be used as red pepper development areas. The technology of land preparation and land management is indispensable in the utilization of peatlands. The study aimed to study the effect of land preparation on soil fertility, growth and yield of red peppers. The research was carried out on peatland in Kalampangan village, Sebangau Sub-District, Kodya Palangkaraya, (-2 ${ }^{\circ} 179$ '9' $S, 144^{\circ} 1$ '31' ' E, 53,8m) from June to October, 2017. The experiment used Split Plot design, 3 replications. The main plot is types of land arrangement $(U 1=$ without rise beds and $U 2=$ with rise beds). The plot is a type of land preparation ( $A 1=$ slash, burn, $A 2=$ slash, compost, $A 3=$ slash, mulch, $A 4=$ slash, compost, plastic mulch). Observations were made on plant growth, soil $\mathrm{pH}$ and $\mathrm{P}$ available on soil and red pepper yields. The highest yield of red pepper was reached on the treatment of land arrangement of beds system combined with land clearing system, then compostable materials + plastic mulch, while the lowest yield on the without bed + soil treatment on slash and weed was used for mulch. The result of pepper plant in peat soil is influenced by soil pH and $P$ concentration is available in soil.
\end{abstract}

Keywords: bed system, slash-burn, slash-compost, slash-mulch, plastic mulch

\begin{abstract}
ABSTRAK
Lahan gambut berpotensi untuk dijadikan areal pengembangan tanaman cabai, namun diperlukan teknologi pengelolaan lahan yang tepat. Salah satu teknologi yang diperlukan adalah teknologi persiapan lahan tanpa bakar dan penataan lahan. Penelitian bertujuan untuk mempelajari pengaruh persiapan dan penataan lahan terhadap kesuburan, pertumbuhan dan hasil tanaman cabai merah. Penelitian dilaksanakan di lahan gambut di desa Kalampangan, Kecamatan Sebangau, Kodya Palangkaraya, pada bulan Juni sampai Oktober 2017. Rancangan percobaan menggunakan Split Plot yang diulang 3 kali. Petak utama adalah jenis penataan lahan ( $\mathrm{U} 1=$ tanpa bedengan dan $\mathrm{U} 2=$ bedengan tinggi $30 \mathrm{~cm})$. Anak Petak adalah jenis persiapan lahan $(\mathrm{A} 1=$ semprot, tebas, bakar, $\mathrm{A} 2=$ tebas, kompos, A3 = tebas, mulsa, A4 = tebas, kompos, mulsa plastik). Pengamatan meliputi tinggi tanaman dan hasil tanaman cabai, $\mathrm{pH}$ tanah dan kadar P tersedia di tanah. Perlakuan yang memberikan hasil cabai tertinggi adalah perlakuan penataan lahan sistem guludan yang dikombinasikan dengan sistem persiapan lahan tebas, kemudian bahan dikomposkan+mulsa plastik, sedangkan hasil paling rendah pada perlakuan penataan lahan tanpa guludan pada sistem persiapan lahan tebas dan gulma digunakan untuk mulsa. Hasil tanaman cabai di tanah gambut berhubungan dengan $\mathrm{pH}$ tanah dan konsentrasi $\mathrm{P}$ tersedia di tanah.
\end{abstract}

Kata kunci: mulsa plastik, sistem bedengan, tebas-bakar, tebas-kompos, tebas-mulsa

\footnotetext{
1) Balai Penelitian Pertanian Lahan Rawa (Balittra)

J1. Kebun Karet, Loktabat, Banjarbaru, South Kalimatan, Indonesia

2) Universitas Lambung Mangkurat - Jurusan Tanah, Fakultas Pertanian

E-mail : eni_balittra@yahoo.com (*Penulis korespondensi)
} 


\section{PENDAHULUAN}

Cabai merupakan salah satu komoditas strategis dan memegang peranan penting dalam stabilitas ekonomi nasional. Cabai merupakan komoditas potensial yang memiliki nilai ekonomi tinggi dan berpotensi untuk terus dikembangkan (Tsurayya dan Kartika, 2015). Komoditas cabai bukan termasuk pangan pokok bagi masyarakat Indonesia, akan tetapi perannya sebagai bumbu pelengkap masakan, ditunjang harganya yang selalu fluktuatif, tak jarang cabai menyumbang inflasi bagi perekonomian nasional (Yanuarti dan Afsari, 2016). Salah satu strategi untuk mengatasi kebutuhan cabai yaitu dengan meningkatkan luas areal tanam terutama pada saat musim hujan (Anwarudin et al., 2015). Semakin meningkatnya kebutuhan cabai menuntut untuk dilakukan upaya peningkatan produksi cabai nasional. Salah satu program pemerintah saat ini adalah swasembada cabai, dengan target produksi cabai pada tahun 2019 sekitar 1.209 juta ton (Kementerian Pertanian, 2015).

Tanaman cabai menghendaki kondisi tanah yang subur dan tidak tergenang dengan ketebalan gambut kurang dari $100 \mathrm{~cm}$. Lahan gambut ketebalan 50-100 cm sesuai untuk tanaman pangan, palawija, dan hortikultura, sedangkan gambut dengan ketebalan $>2 \mathrm{~m}$ terkategori sesuai bersyarat atau bahkan tidak sesuai pada kubah gambut (dome), sedangkan pada kedalaman > 3 m untuk kawasan lindung (konservasi) (Ritung dan Sukarman, 2014). Kesesuaian lahan untuk tanaman cabai merah ditentukan oleh beberapa faktor yaitu; suhu udara, ketersediaan air, ketersediaan oksigen (kondisi drainase), media perakaran, retensi hara, toksisitas, bahaya erosi dan penyiapan lahan (Sitorus, 2017).

Lahan gambut terutama gambut dangkal telah lama dimanfaatkan oleh petani sebagai areal pertanian. Berbagai jenis tanaman mampu tumbuh di lahan gambut dangkal sampai sedang, terutama tanaman palawija dan sayuran, seperti cabai, terong, nenas, kacang panjang dan tanaman hortikultura lainnya (Tim Sintesis Kebijakan, 2008). Tanaman hortikultura telah lama dikembangkan di lahan gambut, seperti di Kalampangan Kaliamantan Tengah dan Rasau Jaya serta Siantan, Kalimantan Barat (Alwi dan Hairani, 2007). Namun dalam pemanfaatan lahan gambut ini masih sering dijumpai beberapa masalah yang berkaitan dengan kesuburan tanah yang rendah serta emisi gas rumah kaca (GRK). Emisi di lahan gambut berasal dari dekomposisi bahan gambut itu sendiri, respirasi akar serta dari kebakaran lahan.

Saat ini petani masih banyak yang menggunakan sistem tebas bakar (slash and burn) baik untuk persiapan lahan maupun untuk mendapatkan abu sebagai bahan amelioran (pembenah tanah), sehingga meningkatkan emisi karbon dan menurunkan umur pakai gambut. Teknologi persiapan lahan tanpa bakar perlu dikembangkan untuk menjaga kelestarian gambut. Salah satu teknologi persiapan lahan dengan memanfaatkan gulma sebagai bahan baku kompos, dan kemudian kompos tersebut dikembalikan sebagai bahan pembenah tanah.

Bahan pembenah tanah sangat diperlukan untuk memperbaiki sifat tanah gambut, sehingga dapat mendukung pertumbuhan tanaman. Kesuburan tanah sangat menentukan keberhasilan pemanfaatan gambut untuk cabai (Alwi dan Hairani, 2007). Pada umumnya lahan gambut mempunyai kesuburan tanah rendah, serta dinamika air yang tidak mendukung pertumbuhan tanaman. Peningkatan kesuburan tanah di lahan gambut dapat dilakukan melalui pemberian amelioran (Maftuah et al., 2013).

Kegiatan budidaya yang berpengaruh terhadap keberhasilan usaha tani cabai di lahan gambut diantaranya adalah persiapan lahan. Persiapan lahan yang tidak tepat selain menyebabkan kegagalan dalam budidaya tanaman juga dapat meningkatkan kerentanan dan emisi di lahan gambut. Upaya untuk mengurangi kerentanan kebakaran dapat dilakukan dengan meningkatkan kelembaban pada permukaan gambut. Teknologi tanpa bakar dapat dilakukan dengan persiapan lahan secara manual maupun mekanik dan dilanjutkan dengan pemberian dekomposer untuk mendekomposisi gulma, kayu dan ranting-ranting sisa tanaman. Persiapan lahan selanjutnya adalah penataan lahan. Penataan lahan dimaksudkan untuk memberikan kondisi tanah dan lingkungan yang optimal untuk mendukung pertumbuhan tanaman. Pada lahan yang tergenang dapat dibuat surjan, sedangkan lahan yang tidak dipengaruhi oleh genangan (tegalan) dengan membuat guludan-guludan kecil (Nursyamsi et al., 2015). Tujuan penelitian ini adalah untuk mempelajari pengaruh persiapan dan penataan lahan 
terhadap kesuburan tanah, pertumbuhan dan hasil tanaman cabai merah.

\section{BAHAN DAN METODE}

Penelitian dilaksanakan di lahan gambut terdegradasi di Desa Kalampangan, Kecamatan Sebagau, Kodya Palangkaraya, pada bulan Juni sampai Oktober 2017. Berdasarkan hasil analisis tanah awal lahan gambut yang digunakan mempunyai kesuburan tanah yang sangat rendah yang ditandai oleh hasil pengukuran $\mathrm{pH} \mathrm{H}_{2} \mathrm{O}$ menggunakan $\mathrm{pH}$ meter (1:5) nilai $\mathrm{pH} 4.67, \mathrm{P}$ tersedia menggunakan Spektrofotometer dengan ekstraksi Bray II nilai $40.98 \mathrm{mg} \mathrm{kg}^{-1}$, K-dd menggunakan Flamefotometer dengan pengestrak $\mathrm{HCl} 25 \%$ dengan nilai K-dd sebesar $3.94 \mathrm{cmol}^{(+)} \mathrm{kg}^{-1}$ (Balittra, 2017).

Penelitian ini merupakan penelitian lapangan dengan perlakuan jenis persiapan lahan dan jenis penataan lahan. Rancangan percobaan menggunakan Split Plot yang diulang 3 kali. Petak utama adalah jenis penataan lahan $(\mathrm{U} 1=$ tanpa bedengan dan $\mathrm{U} 2=$ bedengan tinggi $30 \mathrm{~cm}$ ). Anak Petak adalah jenis persiapan lahan $(\mathrm{A} 1=$ semprot, tebas, bakar, $\mathrm{A} 2$ = tebas, kompos, $\mathrm{A} 3=$ tebas, mulsa, A4 = tebas, kompos, mulsa plastik).

\section{Persiapan Lahan}

Persiapan lahan dilakukan sesuai perlakuan. Persiapan lahan sistem tebas-bakar mempresentasikan kebanyakan yang dilakukan oleh petani, yaitu lahan terlebih dahulu disemprot dengan menggunakan herbisida, kemudian rumput atau gulma yang sudah mati dikumpulkan dan dibakar untuk digunakan sebagai bahan pembenah tanah (A1). Persiapan lahan sistem tebas - kompos (A2), dilakukan tanpa penyemprotan herbisida yaitu gulma ditebas kemudian dikumpulkan untuk dikomposkan. Persiapan lahan sistem tebas mulsa (A3), gulma/rumput ditebas kemudian dikumpulkan untuk digunakan sebagai mulsa. Persiapan lahan pada perlakuan A4 sama dengan $\mathrm{A} 2$, namun diberi mulsa plastik.

Setelah lahan dibersihkan sesuai perlakuan, kemudian lahan diolah (dicangkul) sedalam $30-40 \mathrm{~cm}$ sampai gembur. Ukuran petak yang digunakan dalam percobaan ini untuk masing-masing perlakuan yaitu lebar $5 \mathrm{~m}$ dan panjang $6 \mathrm{~m}$ sehingga luas setiap petak 30 $\mathrm{m}^{2}$. Penataan lahan dilakukan sesuai perlakuan (dengan bedengan) dan tanpa bedengan, di sekeliling petakan dibuat saluran dengan kedalaman $30 \mathrm{~cm}$. Pada perlakuan bedengan, pembuatan bedengan dengan lebar $1.2 \mathrm{~m}$, tinggi $30 \mathrm{~cm}$, dan jarak antar bedengan $30 \mathrm{~cm}$. Lubang tanam sesuai jarak tanam dengan jarak $50 \mathrm{~cm} x$ $40 \mathrm{~cm}$, sehingga setiap bedengan ada 2 baris. Varietas cabai merah yang digunakan adalah Hot Chilli.

\section{Persemaian}

Persemaian dilakukan pada polibag kecil, dengan media pupuk kandang dan tanah gambut dengan perbandingan $1: 1$, selanjutnya diberi sedikit kapur (sekitar 5\%) dari bahan media semai. Sebelum disemai, benih cabai merah direndam dalam air hangat selama 1 jam. Perendaman benih tersebut bertujuan untuk menghilangkan hama atau penyakit yang menempel pada biji dan untuk mempercepat perkecambahan. Kalau ada biji yang mengambang, berarti benih kurang baik, jadi harus disingkirkan. Benih-benih yang tenggelam bisa langsung disemai. Tempat persemaian diberi naungan yang terbuat dari paranet atau dari rumbia. Bibit berada di persemaian selama 3 minggu sampai 1 bulan. Dua minggu sebelum bibit dipindahkan ke lapangan, naungan dikurang atau dijarangkan seeara bertahap dan 5 hari sebelum dipindahkan naungan dibuka seluruhnya.

\section{Penanaman}

Penanaman dilakukan saat bibit sudah berumur 1 bulan (mempunyai 4 - 5 helai daun). Tanam bibit dilakukan pada lubang tanam yang telah dibuat yang berjarak $50 \mathrm{~cm} \mathrm{x} 40 \mathrm{~cm}$. Selanjutnya diberi insektisida berbahan aktif karbofuran (furadan) $1 \mathrm{~g}$ per tanaman 2 hari sebelum tanam. Setelah pindah tanam, disiram air kurang lebih $250 \mathrm{~mL}$ per lubang tanam, pagi atau sore agar dapat tumbuh dan tidak stress. Dan selanjutnya disiram pagi dan sore. Penyulaman maksimal 3-7 hari setelah tanam.

\section{Pemupukan dan Pemeliharaan}

Dosis pemupukan urea (N), SP-36 $\left(\mathrm{P}_{2} \mathrm{O}_{5}\right)$, dan $\mathrm{KCl}\left(\mathrm{K}_{2} \mathrm{O}\right)$ adalah $100-200-120 \mathrm{~kg}$ ha $^{-1}$. Pupuk urea diberikan 3 tahap, 1/3 saat tanam $1 / 3$ saat umur 1 bulan dan $1 / 3$ saat umur 
2 bulan. Pemberian pupuk dengan cara dilarik. Pemeliharaan tanaman meliputi pembersihan gulma, pemasangan ajir, pewiwilan dan pengendalian HPT. Pengendalian hama dan penyakit dilakukan secara teratur apabila ada gejala awal serangan. Dosis rekomendasi urea $(\mathrm{N})$, SP-36 $\left(\mathrm{P}_{2} \mathrm{O}_{5}\right)$, dan $\mathrm{KCl}\left(\mathrm{K}_{2} \mathrm{O}\right)$ adalah $100-$ 200-120 kg ha-1 (BPTP Riau, 1999). Pupuk urea diberikan 3 tahap, 1/3 saat tanam 1/3 saat umur 1 bulan dan $1 / 3$ saat umur 2 bulan.

\section{Pengambilan Sampel dan Analisis}

Pengamatan sampel tanah periodik dilakukan pada fase vegetatif (bulan ke-1), akhir vegetatif (bulan ke-2) dan generatif/akhir (bulan ke-3). Analisis tanah meliputi $\mathrm{pH}$ tanah dan P-tersedia. Analisa $\mathrm{pH}$ tanah menggunakan $\mathrm{pH}$ meter dengan ekstraksi $\mathrm{H}_{2} \mathrm{O}$ dengan perbandingan 1:5, sedangkan $\mathrm{P}$ tersedia menggunakan Spektrofotometer dengan pengestrak Bray II (Balitanah, 2005). Pengamatan pertumbuhan tanaman cabai yaitu tinggi tanaman pada umur 2, 4 dan 6 minggu setelah tanam (MST), jumlah buah per tanaman, dan berat buah cabai. Pengukuran tinggi tanaman dengan cara melakukan pengukuran tanaman mulai dari pangkal akar sampai ujung daun. Jumlah buah dihitung dari buah yang dipanen pada periode panen tertentu, sedangkan berat buah dihitung dari 10 sampel buah yang di panen dari tanaman contoh. Pada penelitian ini, periode panen sampai buah pada tanaman habis terpanen sebanyak 12 kali panen. Tanaman contoh yang diamati sebanyak 8 tanaman setiap petak. Hasil tanaman cabai diperoleh dari rata-rata per petak kemudian di konversi ke hektar.
Analisis data dilakukan terhadap variabel pengamatan berupa analisis ragam dilanjutkan dengan uji Duncan 5\%. Analisis korelasi digunakan untuk mengetahui keeratan hubungan antar variabel pengamatan dan regresi digunakan untuk mengetahui tingkat pengaruh perlakuan dan parameter yang memiliki hubungan.

\section{HASIL DAN PEMBAHASAN}

\section{Pertumbuhan Tanaman}

Perlakuan jenis persiapan dan penataan lahan tidak memberikan interaksi nyata terhadap tinggi tanaman (Tabel 1). Namun dari keragaan tanaman dapat terlihat bahwa perlakuan guludan menghasilkan tinggi tanaman cabai lebih baik dibandingkan tanpa guludan. Meskipun tidak berbeda nyata secara statistika, jenis persiapan lahan yang memberikan pengaruh lebih baik terhadap pertumbuhan tanaman cabai adalah perlakuan A4 yaitu gulma ditebas kemudian dikomposkan dan dikembalikan ke tanah sebagai bahan pembenah tanah + mulsa plastik (Tabel 1).

Perlakuan A4 selain menggunakan kompos sebagai bahan pembenah tanah juga menggunakan mulsa plastik. Penggunaan mulsa plastik menyebabkan pertumbuhan tanaman lebih seragam, dibandingkan yang tidak diberi mulsa. Mulsa menghasilkan buah dengan kandungan klorofil-a, klorofil-b dan total klorofil tertinggi dan juga meningkat jumlah buah per tanaman dan hasil panen cabai (Ashrafuzzaman et al., 2011; Bhardwaj et al., 2011; Sarolia dan Bhardwaj, 2012).

Tabel 1. Pengaruh jenis penataan dan persiapan lahan terhadap tinggi tanaman cabai

\begin{tabular}{cccc}
\hline \multirow{2}{*}{ Perlakuan } & \multicolumn{3}{c}{ Tinggi Tanaman $(\mathrm{cm})$} \\
\cline { 2 - 4 } & 2 MST & 4 MST & 6 MST \\
\hline Petak utama; Penataan lahan & 20.79 & 49.85 & 56.79 \\
U1= tanpa bedengan & 21.00 & 46.04 & 55.00 \\
U2= bedengan tinggi 30 cm & & & \\
Anak petak; Persiapan lahan & 21.79 & 46.42 & 57.58 \\
A1= semprot, tebas, bakar & 19.83 & 45.58 & 52.50 \\
A2= tebas, kompos & 20.83 & 46.21 & 52.54 \\
A3= tebas, mulsa & 21.13 & 53.58 & 61.00 \\
A4= tebas, kompos, mulsa plastik & $20.89 \pm 0.81$ & $47.95 \pm 3.77$ & $55.89 \pm 4.16$ \\
\hline Rerata \pm SD
\end{tabular}


Berdasarkan hasil pengamatan keragaan tanaman pertumbuhan tanaman cabai sangat dipengaruhi oleh mulsa yang digunakan. Perlakuan tanpa mulsa plastik hitam perak (baik yang diberi mulsa gulma insitu maupun tanpa mulsa) terlihat tingkat serangan OPT lebih tinggi dibandingkan yang menggunakan mulsa plastik hitam perak. Perlakuan A3 (penggunaan mulsa dari gulma insitu/alang-alang) meningkatkan serangan hama Trips yang menyebabkan daun keriting. Mulsa dari bahan organik tersebut digunakan oleh hama trips untuk meletakkan telurnya sehingga populasi hama trips meningkat. Seperti disampaikan Setiawati et al. (2013) penggunaan mulsa dari jerami atau sejenisnya dapat meningkatkan serangan hama trips, karena mulsa jerami dapat digunakan untuk peletakan telur hama tersebut.

Lahan gambut mempunyai kelembaban tanah tinggi, terutama saat musim hujan. Curah hujan dan kelembaban tinggi dapat meningkatkan serangan hama trips. Jenis mulsa di lahan gambut yang sesuai adalah mulsa hitam perak. Mulsa hitam perak dapat menurunkan populasi trips karena dapat merefleksikan cahaya dan suhu (Kareem et al., 2012). Refleksi cahaya selain dapat menekan trips, juga dapat meningkatkan penangkapan cahaya oleh tanaman. Fahrurrozi et al. (2001) menyatakan bahwa penangkapan cahaya yang lebih tinggi mengakibatkan proses fotosintesis yang meningkat sehingga hasil tanaman juga meningkat.

\section{Komponen Hasil dan Hasil Cabai}

Perlakuan bedengan tinggi $30 \mathrm{~cm}$ (U2) memberikan pengaruh lebih baik terhadap produksi cabai dibandingkan dengan tanpa bedengan (U1). Berat buah pada perlakuan jenis penataan lahan model bedengan (U2) lebih tinggi dibandingan tanpa bedengan (U1), dan tidak berbeda nyata pada semua jenis persiapan lahan (A) (Tabel 2). Jumlah buah tidak menunjukkan perbedaan pada perlakuan penataan lahan, namun pada perlakuan persiapan lahan menunjukkan perbedaan (Tabel 2).

Salah satu komponen yang menentukan hasil cabai adalah jumlah buah (Chozin dan Ganefianti, 2013). Berdasarkan data tersebut diketahui model bedengan memberikan pengaruh lebih baik dibandingkan tanpa bedengan terhadap berat dan ukuran buah cabai merah. Pembuatan bedengan dapat mengurangi pelindian unsur hara bersamaan dengan aliran air permukaan, meningkatkan pemadatan tanah sehingga perakaran menjadi lebih kokoh, serta mampu menjaga agar lahan tidak tergenang saat banjir.

Tabel 2. Pengaruh jenis penataan lahan dan persiapan lahan terhadap berat buah dan jumlah buah cabai

\begin{tabular}{|c|c|c|}
\hline \multirow[b]{2}{*}{ Perlakuan } & \multicolumn{2}{|c|}{ Komponen Hasil } \\
\hline & $\begin{array}{l}\text { Berat per Buah } \\
(\mathrm{g})\end{array}$ & Jumlah \\
\hline \multicolumn{3}{|l|}{ Petak utama; Penataan lahan } \\
\hline $\mathrm{U} 1=$ tanpa bedengan & $9.83 \mathrm{a}$ & 22.51 \\
\hline $\mathrm{U} 2=$ bedengan tinggi $30 \mathrm{~cm}$ & $10.45 \mathrm{~b}$ & 20.82 \\
\hline \multicolumn{3}{|l|}{ Anak petak; Persiapan lahan } \\
\hline $\mathrm{A} 1=$ semprot, tebas, bakar & 10.76 & 28.40 \\
\hline $\mathrm{A} 2=$ tebas, kompos & 11.11 & 22.00 \\
\hline $\mathrm{A} 3=$ tebas, mulsa & 10.67 & 26.46 \\
\hline $\mathrm{A} 4=$ tebas, kompos, mulsa plastik & 10.82 & 24.40 \\
\hline Rerata \pm SD & $10.61 \pm 0.43$ & $24 \pm 2.89$ \\
\hline
\end{tabular}




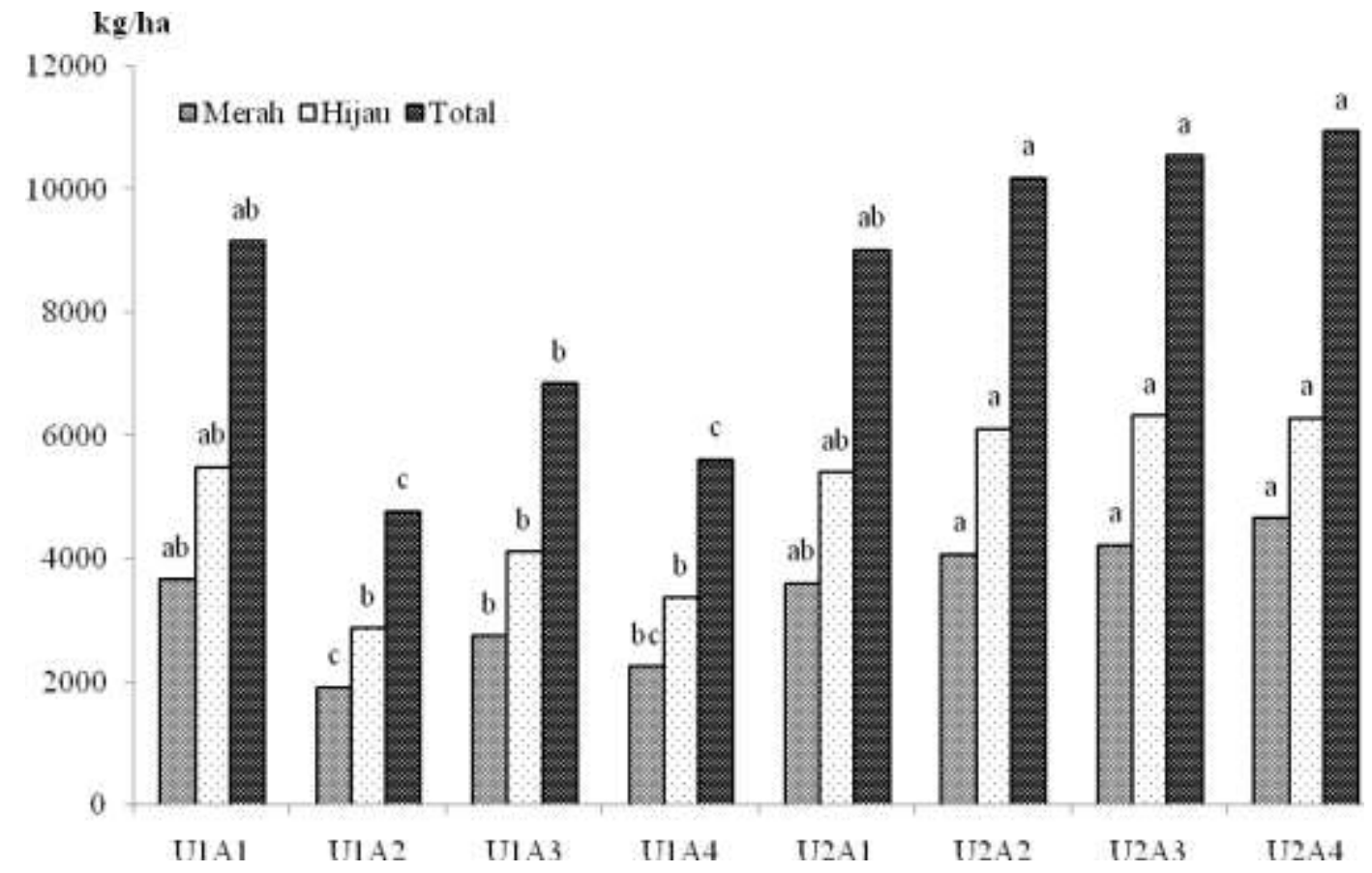

Gambar 1. Pengaruh persiapan dan penataan lahan terhadap hasil buah cabai.

Jenis penataan lahan dan persiapan lahan menunjukkan interaksi terhadap hasil tanaman cabai baik cabai yang dipanen merah, hijau maupun total (merah+hijau) (Gambar 1). Perlakuan yang memberikan hasil cabai tertinggi mencapai 9.8 ton ha $^{-1}$ adalah perlakuan penataan lahan sistem bedengan yang dikombinasikan dengan sistem persiapan lahan tebas, kemudian bahan dikomposkan + mulsa plastik (U2A4), sedangkan hasil paling rendah pada perlakuan penataan lahan tanpa guludan pada sistem persiapan lahan tebas dan gulma digunakan untuk mulsa (U1A2) mencapai 4.5 ton $\mathrm{ha}^{-1}$. Hasil penelitian ini lebih tinggi dibandingkan dengan rata-rata produksi cabai di Kalimantan Tengah yaitu sekitar 3.13 ton $\mathrm{ha}^{-1}$ (Anto, 2014).

\section{Perubahan Sifat Tanah (pH dan P tersedia)}

Perlakuan jenis penataan lahan dan persiapan lahan tidak memberikan pengaruh nyata terhadap $\mathrm{pH}$ tanah pada periode pengamatan bulan ke-2 dan ke-3, namun pada bulan pertama menunjukkan perbedaan (Tabel 3). Secara umum terjadi penurunan $\mathrm{pH}$ tanah pada perlakuan tanpa bedengan (U1) pada pengamatan bulan ke-2, sedangkan pada bulan ke-3 terjadi peningkatan $\mathrm{pH}$. Kemasaman tanah gambut erat kaitannya dengan keberadaan asam- asam organik. Dekomposisi bahan organik akan melepaskan asam-asam organik sehingga dapat meningkatkan kemasaman gambut. Karbon organik akan menyumbangkan $\mathrm{H}^{+}$dalam sintesis asam-asam organik. Asam organik memberikan kontribusi yang nyata terhadap rendahnya $\mathrm{pH}$ tanah gambut (Susanti, 2015).

Menurut Sabiham (2006), faktor-faktor yang mempengaruhi beragamnya kesuburan tanah gambut adalah ketebalan lapisan gambut, tingkat dekomposisi, komposisi bahan tanaman penyusun gambut, bahan tanah mineral yang berada di bawah lapisan gambut, dan kualitas air atau lingkungan selama proses pembentukan gambut. Keberagaman sifat kimia tanah gambut juga disebabkan oleh kesudahan reklamasi dan intensitas pemanfaatannya.

Pengaruh jenis penataan lahan dan persiapan lahan terhadap $\mathrm{P}$ tersedia tanah seperti disajikan pada Tabel 4. Pada bulan pertama tidak terjadi perbedaan nyata antara penataan lahan sistem bedengan dengan bedengan tinggi $30 \mathrm{~cm}$, namun pada bulan ke-2 dan ke-3 terjadi perbedaan. Ketersediaan $\mathrm{P}$ pada tanah gambut umumnya rendah, yang disebabkan kemampuan gambut dalam menjerap pupuk $\mathrm{P}$ rendah. Gugus-gugus reaktif seperti karboksilat menjerap P dengan kekuatan ikatan yang lemah (Stevenson, 1994). 
Pemberian pupuk $\mathrm{P}$ dan bahan pembenah tanah dapat meningkatkan ketersediaan $P$. Ketersediaan $\mathrm{P}$ tertinggi ditunjukkan oleh perlakuan bedengan, dengan persiapan lahan sistem tebas, kemudian gulma dikomposkan untuk bahan pembenah tanah dan diberi mulsa plastik (U2A4).

Penataan lahan menggunakan bedengan tinggi $30 \mathrm{~cm}$ meningkatkan ketersediaan $\mathrm{P}$ tanah. Perlakuan penyiapan lahan dengan gulma ditebas kemudian dibuat kompos untuk bahan pembenah tanah dan diberi mulsa plastik (A4) dapat meningkatkan ketersediaan hara $\mathrm{P}$ pada tanah gambut. Peningkatan konsentrasi $\mathrm{P}$ tersedia tanah pada perlakuan ini dapat terjadi secara langsung maupun tidak langsung. Peningkatan konsentrasi $\mathrm{P}$ secara langsung melalui sumbangan hara dari kompos tersebut, sedangkan tidak langsung melalui pengurangan kehilangan $\mathrm{P}$ melalui pelindian dari areal perakaran akibat terikat oleh kation logam. Pembuatan bedengan menyebabkan hara lebih lama bertahan pada lingkungan perakaran. Penambahan bahan pembenah tanah dengan kation-kation basa diharapkan dapat mengurangi jumlah $\mathrm{P}$ yang terlindi, karena kation tersebut dapat berperan sebagai jembatan kation (Maftuah, 2012).

Tabel 3. Pengaruh jenis penataan lahan dan persiapan lahan terhadap $\mathrm{pH}$ tanah

\begin{tabular}{cccc}
\hline \multirow{2}{*}{ Perlakuan } & \multicolumn{3}{c}{$\mathrm{pH}$} \\
\cline { 2 - 4 } & Bulan Ke-1 & Bulan Ke-2 & Bulan Ke-3 \\
\hline Petak utama: Penataan lahan & & & \\
U1= tanpa bedengan & $4.67 \mathrm{a}$ & 4.33 & 4.58 \\
U2= bedengan tinggi $30 \mathrm{~cm}$ & $4.28 \mathrm{~b}$ & 4.37 & 4.43 \\
Anak petak: Penyiapan lahan & & & \\
A1= semprot, tebas, bakar & $4.67 \mathrm{a}$ & 4.39 & 4.51 \\
A2= tebas, kompos & $4.29 \mathrm{c}$ & 4.37 & 4.56 \\
A3= tebas, mulsa & $4.49 \mathrm{~b}$ & 4.36 & 4.46 \\
A4= tebas, kompos, mulsa plastik & $4.46 \mathrm{~b}$ & 4.28 & 4.49 \\
\hline Rerata \pm SD & $4.47 \pm 0.17$ & $4.35 \pm 0.14$ & $4.50 \pm 0.06$ \\
\hline
\end{tabular}

Keterangan: Angka yang disertai huruf yang sama tidak berbeda nyata berdasarkan uji Duncan 5\%.

Tabel 4. Pengaruh jenis penataan lahan dan persiapan lahan terhadap P tersedia tanah

\begin{tabular}{cccc}
\hline \multirow{2}{*}{ Perlakuan } & \multicolumn{3}{c}{ P Tersedia $\left(\mathrm{mg} \mathrm{kg}^{-1}\right)$} \\
\cline { 2 - 4 } & Bulan Ke-1 & Bulan Ke-2 & Bulan Ke-3 \\
\hline Petak utama: Penataan lahan & $198.50 \mathrm{a}$ & $199.50 \mathrm{~b}$ & $99.25 \mathrm{~b}$ \\
U1= tanpa bedengan & $165.50 \mathrm{a}$ & $262.00 \mathrm{a}$ & $120.88 \mathrm{a}$ \\
U2= bedengan tinggi $30 \mathrm{~cm}$ & & & \\
Anak petak: Penyiapan lahan & $203.00 \mathrm{a}$ & $214.00 \mathrm{~b}$ & $89.50 \mathrm{c}$ \\
A1= semprot, tebas, bakar & $167.50 \mathrm{~b}$ & $209.50 \mathrm{~b}$ & $113.75 \mathrm{~b}$ \\
A2= tebas, kompos & $193.00 \mathrm{a}$ & $133.50 \mathrm{c}$ & $76.75 \mathrm{c}$ \\
A3= tebas, mulsa & $164.50 \mathrm{~b}$ & $366.00 \mathrm{a}$ & $160.25 \mathrm{a}$ \\
A4= tebas, kompos, mulsa plastik & $182 \pm 32.32$ & $230 \pm 34.17$ & $110 \pm 24.74$ \\
\hline Rerata \pm SD &
\end{tabular}

Keterangan: angka yang disertai huruf yang sama tidak berbeda nyata berdasarkan uji Duncan $5 \%$.

Tabel 5. Koefisien korelasi antar variabel pengamatan 


\begin{tabular}{lllllll}
\hline \multicolumn{1}{c}{$\begin{array}{c}\text { Variabel } \\
\text { Pengamatan }\end{array}$} & \multicolumn{1}{c}{$\begin{array}{c}\text { Tinggi } \\
\text { Tanaman }\end{array}$} & $\begin{array}{c}\text { Berat } \\
\text { Buah }\end{array}$ & $\begin{array}{c}\text { Jumlah Buah } \\
\text { per Tanaman }\end{array}$ & $\begin{array}{c}\text { Hasil per } \\
\text { ha }\end{array}$ & $\begin{array}{c}\mathrm{pH} \\
\text { Tanah }\end{array}$ & P Tersedia \\
\hline $\begin{array}{l}\text { Tinggi tanaman } \\
\text { Berat buah }\end{array}$ & -0.41 & & & & & \\
Jumlah buah per & 0.29 & 0.34 & & & & \\
tanaman & & & & & & \\
Hasil per ha & 0.36 & $0.62^{* *}$ & $0.94^{* *}$ & & & \\
pH tanah & 0.38 & 0.27 & 0,29 & 0.36 & & \\
P tersedia & $0.56^{*}$ & 0.24 & 0.03 & 0.07 & $0.56^{*}$ & \\
\hline
\end{tabular}

\section{Korelasi Antar Variabel Pengamatan}

Hasil analisis korelasi antar variabel pengamatan tinggi tanaman, hasil tanaman cabai dan sifat tanah ( $\mathrm{pH}$ dan $\mathrm{P}$ tersedia), seperti disajikan pada Tabel 5. Berdasarkan hasil analisis korelasi tinggi tanaman dan hasil tanaman cabai berhubungan positif dengan sifat tanah yaitu $\mathrm{pH}$ tanah dan $\mathrm{P}$ tersedia tanah. Menurut Nazir et al. (2017) terdapat hubungan $\mathrm{pH}$ tanah dengan ketersediaan unsur hara. Kadar $\mathrm{P}$ dalam tanah berhubungan dengan pertumbuhan dan produksi cabai. Kadar P tanah sangat terkait dengan kadar P dalam tanaman. Tanaman mengandung P sekitar $0.2 \%$ dari berat kering (Bagyaraj et al., 2015). Unsur $\mathrm{P}$ berkaitan erat dengan penyusunan bagian penting tanaman seperti asam nukleat pada inti sel, berperan dalam reaksi biokimia dalam metabolisme karbohidrat, lemak dan protein. Senyawa fosfolipid bertindak sebagai intermedier, menyimpan dan penyedia energi reaksi-reaksi khusus seperti pada respirasi dan fermentasi (Soepardi, 1983).

Fosfor merupakan unsur yang paling kritis dibandingkan unsur-unsur lainnya bagi tanaman (Tanwar et al., 2013). Dibandingkan dengan nutrisi utama lainnya, fosfor merupakan unsur hara yang kurang tersedia untuk tanaman (Khan et al., 2007). Kekurangan unsur tersebut dapat menyebabkan tanaman tidak mampu menyerap unsur lainnya, meskipun jumlah unsur fosfor yang diangkut tanaman sedikit, akan tetapi karena efisiensi penggunaan fosfor dari pupuk sangat penting. Unsur $\mathrm{P}$ sangat penting bagi tanaman antara lain untuk pembelahan sel, perkembangan akar, pembentukan bunga dan buah. Sejalan dengan pertumbuhan vegetatif tanaman yang memiliki tinggi tanaman dan bobot kering tanaman yang relatif tinggi cendrung menghasilkan buah cabai yang lebih tinggi pula (Rosliani, 1997).

\section{KESIMPULAN}

Perlakuan jenis persiapan dan penataan lahan tidak memberikan pengaruh nyata terhadap tinggi tanaman cabai, namun berpengaruh nyata terhadap hasil cabai. Perlakuan yang memberikan hasil cabai tertinggi adalah perlakuan penataan lahan sistem bedengan yang dikombinasikan dengan sistem persiapan lahan tebas, kemudian bahan dikomposkan + mulsa plastik (U2A4), sedangkan hasil paling rendah pada perlakuan penataan lahan tanpa guludan pada sistem persiapan lahan tebas dan gulma digunakan untuk mulsa (U1A2). Perlakuan yang dapat meningkatkan ketersediaan $\mathrm{P}$ adalah perlakuan guludan dan sistem persiapan lahan tebas, kemudian bahan dikomposkan + mulsa plastik (U2A4).

\section{UCAPAN TERIMAKASIH}

Penulis mengucapkan terimakasih kepada Badan Litbang Pertanian, Kementerian Pertanian yang telah mendanai penelitian ini dengan proyek SMARTD melalui program Kerjasama Penelitian, Pengkajian dan Pengembangan Pertanian Strategis (KP4S).

\section{DAFTAR PUSTAKA}

Alwi, M., A. Hairani. 2007. Karakteristik kimia lahan gambut dangkal dan potensinya untuk pertanaman cabai dan tomat. Bul. Agron. 35(1): 36-43.

Anto, A. 2014. Uji adaptasi lima varietas cabai merah di lahan gambut Palangkaraya Kalimantan Tengah. Agripura. 8(1): 1037-1040.

Syah, M.J.A, A.L. Sayekti, A.M. Kiloes, Y. Hilman. 2015. Dinamika produksi dan volatilitas harga cabai: antisipasi strategi 
dan kebijakan pengembangan. Pengembangan Inovasi Pertanian. 8(1): $33-42$.

Ashrafuzzaman, M., A. Halim, M.R. Ismail, S.M. Shahidullah, M.A. Hossain. 2011 Effect of plastic mulch on growth and yield of chilli (Capsicum annuum L.). Brazilian Archives of Biology and Technology. 54(2): 321-330.

Balittra. 2017. Laporan Akhir Hasil Penelitian. Balai Penelitian Pertanian Lahan Rawa. Banjarbaru.

Balittanah. 2005. Petunjuk Teknis Analisis Kimia Tanah, Tanaman, Air dan Pupuk. Badan Litbang Pertanian. Departemen Pertanian. Bogor. 313 Halaman.

BPTP Riau. 1999. Budidaya Cabai di Lahan Gambut. Liptan. Kementerian Pertanian.

Bagyaraj, D.J., M.P. Sharma, D. Maiti. 2015. Phosphorus nutrition of crops through arbuscular mycorrhizal fungi. Current Science. 108(7): 1288-1292.

Bhardwaj, R.L. 2011. Bench mark survey on effect of mulching material on crop production. Krishi Vigyan Kendrs, Sirohi, MPUAT Udaipur. pp. 12-15.

Fahrurrozi, K.A. Stewart, S. Jenni. 2001. The early growth of muskmelon in mulched mini-tunnel containing a thermal-water tube. i. the carbon dioxide concentration in the tunnel. J. Amer. Soc. For Hort. Sci. 126: 757- 763.

Chozin, M., D.W. Ganefianti. 2013. Correlation and path analysis for determination of selection criteria in chilli pepper breeding for fruit yield improvement. Proceedings The 3th International Symposium for Sustainable Humanosphere (ISSH). A Forum of Humanosphere Science School (HSS), Bengkulu, pp. 114-117.

Kementerian Pertanian, 2015. Rencana strategis Kementerian Pertanian tahun 2015-2019.
Khan, M. S., A. Zaidi, P.A. Wani. 2007. Role of phosphate - solubilizing microorganisms in sustainable agriculture - A review. Agron. Sustain. Dev. 27: 29-43.

Khan, M.J., W. Drochner, H. Steingass, K.M.S. Islam. 2008. Nutritive evaluation of some tree leaves from Bangladesh for feeding ruminant animals. Indian $\mathbf{J}$. Anim. Sci. 78(11): 1273-1277.

Kareem, K.T., O.O. Alamu, R.K. Egberongbe, O. Arogundade. 2012. Effect of different mulch materials on the incidence and severity of okra mosaic virus (OMV) in okra plants. Journal of Applied Horticulture. 14(1): 1-14.

Maftuah, E. 2012. Ameliorasi lahan gambut terdegradasi dan pengaruhnya terhadap produksi tanaman jagung manis. Disertasi. Universitas Gadjah Mada. Yogyakarta. 251 hal.

Maftuah, E., A. Maas, A. Syukur, B.H. Purwanto. 2013. Efektivitas amelioran pada lahan gambut terdegradasi untuk meningkatkan pertumbuhan dan serapan NPK tanaman jagung manis (Zea mays L. saccharata). J. Agron. Indonesia. 41(1): 16-23.

Nazir, M., Syakur, Muyassir. 2017. Pemetaan kemasaman tanah dan analisis kebutuhan kapur di kecamatan Keumala Kabupaten Pidie. JIM Pertanian Unsyiah. 2(1): 21-30.

Nursyamsi, D., M. Noor, Haryono. 2015. Sistem surjan. Model Pertanian Lahar Rawa Adaptif Perubahan Iklim. IAARD Press.

Ritung, S., Sukarman. 2014. Kesesuaian Lahan Gambut Untuk Pertanian. Hal: 61-83. Dalam F. Agus, M. Anda, A. Jamil, Masganti (Eds). Lahan Gambut Indonesia: Pembentukan, Karakteristik, Dan Potensi Mendukung Ketahanan Pangan. Badan Penelitian dan Pengembangan Pertanian. Kementerian Pertanian.

Rosliani, R. 1997. Pengaruh pemupukan dengan pupuk majemuk makro berbentuk tablet terhadap pertumbuhan 
dan hasil cabai merah. J. Hort. 7: 773780 .

Sabiham, S. 2006. Pengelolaan Lahan Gambut Indonesia Berbasis Keunikan Ekosistem. Orasi Ilmiah Guru Besar tetap Pengelolaan Tanah. Fakultas Pertanian Institut Pertanian Bogor, Bogor.

Sarolia, D.K., R.L. Bhardwaj. 2012. Effect of mulching on crop production under rainfed condition: A Review. Int. J. Res. Chem. Environ. 2: 8-20.

Setiawati, W., N. Sumarni, Y. Koesandriani, A. Hasyim, T.S. Uhan, R. Sutarya. 2013. Penerapan teknologi pengendalian hama terpadu pada tanaman cabai merah untuk mitigasi dampak perubahan iklim (Implementation of integrated pest management for mitigation of climate change on chili peppers. J. Hort. 23(2): 174-183.

Sitorus, A. 2017. Evaluasi kesesuian lahan untuk budidaya komoditi unggulan di Kecamatan Siempat Rube Kabupaten Pakpak Bharat. Tesis. USU. Medan. Hal: 219.

Soepardi, G. 1983. Sifat dan Ciri Tanah. Fakultas Pertanian, Pustaka Buana, Bandung.

Stevenson, F.J. 1994. Humus Chemistry: Genesis, composition, and reaction.
Edisi ke 2. John Wiley \& Sons, Inc. New York.

Susanti, M.A. 2015. Dampak penggunaan pestisida dan pengelolaan air terhadap kualitas lingkungan dan emisi karbon di lahan gambut yang disawahkan. Disertasi. Institut Pertanian Bogor, Bogor. Hal: 122.

Tanwar, A., A. Aggarwal, N. Kadian, A. Gupta. 2013. Arbuscular mycorrhizal inoculation and super phosphate application influence plant growth and yield of Capsicum annuum. Journal of Soil Science and Plant Nutrition. 13(1): 55-66.

Tim Sintesis Kebijakan. 2008. Pemanfaatan dan konservasi lahan rawa gambut di Kalimantan. Pengembangan Inovasi Pertanian. 1(2): 149-156.

Tsurayya, S., L. Kartika, 2015. Kelembagaan dan strategi peningkatan daya saing komoditas cabai Kabupaten Garut. Jurnal Manajemen \& Agribisnis. 12(1): $1-13$.

Yanuarti A.R., M.D. Afsari. 2016. Profil komoditas barang kebutuhan pokok dan barang penting komoditas cabai. 1-67. 